\title{
ACUTE CARDIOVASCULAR RESPONSE TO PRE-PRANDIAL AND POSTPRANDIAL EXERCISE IN ACTIVE MEN
}

\author{
RESPOSTA CARDIOVASCULARAGUDA AO EXERCÍCIO PRÉ E PÓS-PRANDIAL EM HOMENS ATIVOS
}

riginal Article

RESPUESTA CARDIOVASCULARAGUDA AL EJERCICIO PREPRANDIAL Y POSTPRANDIAL

ARTIGO ORIGINAL

Artículo Original

\section{EN HOMBRES ACTIVOS}

\begin{abstract}
Márcio Rabelo Mota (Physical Education Professional)

Sandro Nobre Chaves ${ }^{2}$

(Physical Education Professional)

Maurílio Tiradentes Dutra²

(Physical Education Professional)

Ricardo Jacó de Oliveira²

(Physical Education Professional)

Renata Aparecida Elias Dantas ${ }^{1}$

(Physical Education Professional)

Filipe Dinato de Lima²

(Physical Education Professional)
\end{abstract}

1. Centro Universitário de Brasília (UniCEUB), Faculdade de Ciências da Educação e da Saúde, Brasília, DF, Brazil.

2. Universidade de Brasília (UnB), Faculdade de Educação Física, Brasília, DF, Brazil.

\section{Correspondência:}

Maurílio Tiradentes Dutra

Faculdade de Educação Física.

Campus Universitário Darcy

Ribeiro, Asa Norte, Brasília,

Distrito Federal, Brazil. 70910-970.

mauriliotiradentes@gmail.com

\begin{abstract}
Introduction: Pre-prandial exercise promotes greater mobilization of fat metabolism due to the increased release of catecholamines, cortisol, and glucagon. However, this response affects how the cardiovascular system responds to exercise. Objective: To evaluate the response of systolic, diastolic, and mean blood pressure, heart rate (HR) and rate-pressure product (RPP) to pre- and postprandial exercise. Methods: Ten physically active male subjects ( $25.50 \pm 2.22$ years) underwent two treadmill protocols (pre- and postprandial) performed for 36 minutes at $65 \%$ of $\mathrm{VO}_{2}$ max on different days. On both days, subjects attended the laboratory on a 10-hour fasting state. For the postprandial session, volunteers ingested a pre-exercise meal of $349.17 \mathrm{kcal}$ containing $59.3 \mathrm{~g}$ of carbohydrates (76.73\%), $9.97 \mathrm{~g}$ of protein (12.90\%), and $8.01 \mathrm{~g}$ of lipids (10.37\%). Blood pressure, HR and RPP were measured before and after exercise. The $2 \times 2$ factorial Anova with the multiple comparisons test of Bonferroni was applied to analyze cardiovascular variables in both moments (pre- vs. postprandial). The significance level was set at $p<0.05$. Results: Systolic (121.70 \pm 7.80 vs. $139.78 \pm 12.91 \mathrm{mmHg})$ and diastolic blood pressure $(66.40 \pm 9.81$ vs. $80.22 \pm 8.68 \mathrm{mmHg})$ increased significantly after exercise only in the postprandial session $(p<0.05)$. HR increased significantly $(p<0.05)$ after both protocols $(64.20 \pm 15.87 \mathrm{vs} .141 .20 \pm 10.33 \mathrm{bpm}$ pre-prandial and $63.60 \pm 8.82 \mathrm{vs.} 139.20 \pm 10.82$ bpm postprandial). RPP had a similar result $(8052.10 \pm 1790.68$ vs. $18382.60 \pm 2341.66 \mathrm{mmHg} . b p m$ in the pre-prandial session and $7772.60 \pm 1413.76$ vs. $19564.60 \pm 3128.99 \mathrm{mmHg} . \mathrm{bpm}$ in the postprandial session). Conclusion: These data suggest that fasted exercise does not significantly alter the blood pressure. Furthermore, the meal provided before the postprandial exercise may promote a greater blood pressure responsiveness during exercise.
\end{abstract}

Keywords: exercise; fasting; postprandial period; blood pressure; heart rate.

\section{RESUMO}

Introdução: Oexercício pré-prandial promove maior mobilização do metabolismo de gordura devido ao aumento da liberação de catecolaminas, cortisol e glucagon. Contudo, tal resposta afeta a form a como o sistema cardiovascular responde ao exercício. Objetivo: Avaliar a resposta da pressão sistólica, diastólica e média, a frequência cardiaca (FC) e o duplo produto (DP) ao exercício prée pós-prandial. Métodos: Dez indivíduos ativos (25,50 2,22 anos) foram submetidos a dois protocolos de exercício em esteira (pré e pós-prandial) realizados durante 36 minutos a $65 \%$ do $\mathrm{VO}_{2}$ máx em dias diferentes. Em ambos os dias, os indivíduos compareceram ao laboratório em jejum de 10 horas. Para a sessão pós-prandial, os voluntários ingeriram uma refeição pré-exercício de 349,17 kcal, contendo 59,3 g de carboidratos (76,73\%), 9,97 g de proteína (12,90\%) e 8,01 g de lipídeos (10,37\%). A pressão sanguínea, a FC e o DP foram medidos antes e depois do exercício. A Anova fatorial (2X2) com as comparações múltiplas de Bonferroni foi aplicada para análise das variáveis nos dois momentos (pré e pós-prandial). O nível de significância foi fixado em $p<$ 0,05. Resultados: A pressão sanguínea sistólica $(121,70 \pm 7,80 \mathrm{vs}$. 139,78 $\pm 12,91 \mathrm{mmHg})$ e a diastólica $(66,40 \pm 9,81 \mathrm{vs}$. $80,22 \pm 8,68 \mathrm{mmHg}$ ) aumentaram significantemente após o exercício somente na sessão pós-prandial $(p<0,05)$. AFC aumentou significantemente $(p<0,05)$ após ambos os protocolos $(64,20 \pm 15,87 \mathrm{vs}$. $141,20 \pm 10,33$ bpm pré-prandial

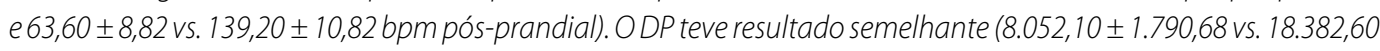
$\pm 2.341,66 \mathrm{mmHg} .6 p m$ na sessão pré-prandial e $7.772,60 \pm 1.413,76 \mathrm{vs} .19 .564,60 \pm 3.128,99 \mathrm{mmHg} .6 p m$ na sessão pós-prandial). Conclusão: Esses dados sugerem que o exercício em jejum não altera significantemente a pressão sanguínea. Além disso, a refeição fornecida antes do exercício pós-prandial pode promover maior responsividade da pressão sanguínea durante o exercício.

Descritores: exercício; jejum; período pós-prandial; pressão sanguínea; frequência cardíaca.

\section{RESUMEN}

Introducción: El ejercicio preprandial promueve una mayor movilización de metabolismo de la grasa debido al aumento de la liberación de catecolaminas, cortisol y glucagón. Sin embargo, tal respuesta afecta la forma en que el sistema cardiovascular responde al ejercicio. Objetivo: Evaluar la respuesta de la presión sistólica, diastólica y media, la frecuencia cardíaca (FC) y el doble-producto (DP) al ejercicio pre y postprandial. Métodos: Diez hombres activos 
(25,50 $\pm 2,22$ años), fueron sometidos a dos protocolos de ejercicio en cinta rodante (prey postprandial) realizados durante 36 minutos a 65\% del VO $\mathrm{V}_{2}$ máx en días diferentes. En ambos días, los individuos asistieron al laboratorio después de un ayuno de 10 horas. Para la sesión postprandial, los voluntarios ingirieron una comida pre-ejercicio de 349,17 kcal, que contenía 59,3 g de hidratos de carbono (76,73\%), 9,97 g de proteínas (12,90\%) y 8,01 g de lípidos (10,37\%). La presión sanguínea, la FC y el DP se midieron antes y después del ejercicio. Se aplicó el ANOVA factorial (2 $\times 2$ ) con las comparaciones múltiples de Bonferroni para analizar las variables en los dos momentos (pre y postprandial). El nivel de significación se ha fijado en $p<0,05$. Resultados: La presión sanguínea sistólica $(121,70 \pm 7,80$ vs. $139,78 \pm 12,91 \mathrm{mmHg})$ y la diastólica $(66,40 \pm 9,81$ vs. $80,22 \pm 8,68 \mathrm{mmHg})$ aumentaron significativamente después del ejercicio sólo en la sesión postprandial $(p<0,05)$. La FC aumentó significativamente $(p<0,05)$ después de ambos protocolos $(64,20 \pm 15,87 \mathrm{vs} .141,20 \pm 10,33 \mathrm{lpm}$ preprandial y $63,60 \pm 8,82 \mathrm{vs} .139,20$ $\pm 10,82$ lpm postprandial). El DP tuvo un resultado similar $(8.052,10 \pm 1.790,68 \mathrm{vs} .18 .382,60 \pm 2.341,66 \mathrm{mmHg}$. Ipm preprandial y 7.772,60 $\pm 1.413,76$ vs. $19.564,60 \pm 3.128 .99$ mm Hg.Ipm postprandial). Conclusión: Estos datos sugieren que el ejercicio en ayunas no altera significativamente la presión sanguínea. Además, la comida suministrada antes del ejercicio postprandial puede promover una mayor capacidad de respuesta de la presión sanguínea durante el ejercicio.

Descriptores: ejercicio; ayuno; periodo posprandial; presión sanguínea; frecuencia cardíaca.

\section{INTRODUCTION}

Aerobic exercise in the fasting state has been used as a strategy for body fat reduction due to increased mobilization of fat metabolism ${ }^{1,2}$. During physical activity in the fasting state, lipolysis is increased and promotes a subsequent increase in plasma concentrations of triglycerides and its subcomponents glycerol and free fatty acids ${ }^{3,4}$. This phenomenon occurs as a consequence of a marked catecholamine secretion and a greater sensitivity of the adipose tissue to these hormones generated by exercise ${ }^{5}$. In addition, exercise in a fasting state causes an increased release of glucagon and cortisol, favoring the use of fat as energy substrate once glycogenolysis becomes restricted by the depletion of muscle and liver glycogen ${ }^{6-8}$. In this sense, the mobilization of triglycerides reserves with decreased metabolism of carbohydrates aims to preserve the glucose concentration in the blood, in order to supply the central nervous system and red blood cells?

The variation of the endocrine response induced by food intake or by fasting seems to influence the response of the cardiovascular system to physical activity. For instance, regulation of blood pressure (BP) responds to plasma catecholamine ${ }^{10}$. Meanwhile, the variation in plasma concentration of norepinephrine necessary for maintaining normal levels of BP is facilitated by the ingestion of glucose and the subsequent release of insulin ${ }^{11}$. Thus, the reduction in the concentration of this neurotransmitter may limit the activation of $\beta$-adrenergic receptor and reduce cardiac contractility ${ }^{12}$. Accordingly, abnormally large falls in BP after a meal (postprandial hypotension) occurs due to the absence of elevated levels of catecholamine and may indicate a dysfunction of the sympathetic nervous system ${ }^{13}$. In addition, insulin response induced by glucose consumption can cause changes in the stimulation of the autonomic nervous system affecting the regulation of $\mathrm{BP}^{14}$.

On the other hand, the increase of insulin secretion has a vasodilator effect, which is elicited by an increase of nitric oxide release by the vascular endothelial cells, causing a reduction in $\mathrm{BP}^{15}$. This increase in insulin secretion alters the action of the arterial baroreceptors, resulting in a reduction in baroreflex sensitivity. This phenomenon causes tachycardia in response to insulin ${ }^{16}$. However, BP appears to respond to other factors related to food intake, such as the volume ingested, and not only the glucose concentration. There is evidence in previous literature that a high volume may attenuate postprandial hypotension because of the increased gastric distension ${ }^{17}$. Yet, the magnitude of these changes is dependent on several factors such as age and gender ${ }^{18}$.
Despite the diversity of studies evaluating the cardiovascular changes induced by fasting and by glucose intake, little evidence is available about the acute cardiovascular responses to exercise in fasting and after food intake. Therefore, the aim of this study was to analyze the acute response of $B P$, heart rate (HR) and rate-pressure product (RPP) of young men during exercise in fasting and postprandial conditions.

\section{MATERIALS AND METHODS}

Ten men aged between 20 and 30 years were invited to participate. All subjects provided written informed consent (consent form). They were not smokers or drinkers and had no musculoskeletal injuries. None of the participants had medical history of metabolic or cardiovascular pathologies and were not taking antihypertensive medications. All subjects were physically active with a minimum volume of 150 minutes per week of aerobic exercise for at least 12 months. This study was approved by the Research Ethics Committee of the University Center of Brasilia, Brazil (protocol 858.452/2014).

Assessments were carried out on three different days with an interval of 72 hours. Subjects were asked to refrain from physical activity and ergogenic resources from 48 hours before the start of the study until the end of the tests. On the first day, participants underwent anthropometric measurements, assessment of maximal oxygen consumption and BP at rest. The level of physical activity was assessed adopting a questionnaire designed by the researchers. Body mass was measured to the nearest $50 \mathrm{~g}$ on a digital scale (Filizola, São Paulo, Brazil). Height was measured to the nearest $0.1 \mathrm{~cm}$ on a stadiometer (Sanny, American Medical of Brazil, São Paulo, Brazil). Body mass index (BMI) was calculated as weight divided by height squared. Body fat percentage was estimated by skinfold method (Cescorf Sporting Equipment, Porto Alegre, Brazil) adopting a 7-fold protocol ${ }^{19}$.

Maximum oxygen uptake was estimated by a maximum incremental treadmill test (RUN 700, Techno Gym, Rio de Janeiro, Brazil) without inclination. The test consisted of an initial speed of $5 \mathrm{~km} / \mathrm{h}$ with increments of $1 \mathrm{~km} / \mathrm{h}$ every minute. The test stopped when the subject reached volitional exhaustion or when maximum $\mathrm{HR}$ estimated by the formula 220-age was achieved. To estimate $\mathrm{VO}_{2}$ max, the ventilometer $\mathrm{VO}_{2}$ ProFitness (CEFISE Biotechnology Sports, Nova Odessa, Brazil) was used.

\section{Experimental protocol}

The volunteers performed two sessions of aerobic exercise (Fasting and Postprandial). Sessions were randomized and separated by 72 hours. 
Both protocols occurred in the morning ( $7 \mathrm{am})$ and were preceded by a fasting period of 10 hours. In the fasted protocol, subjects remained at rest for 15 minutes prior to exercise. In the postprandial protocol, participants were provided with a $349.17 \mathrm{kcal}$ meal consisting of yoghurt, whole wheat cookies, bananas, and a cereal bar, containing $59.3 \mathrm{~g}$ of carbohydrate (76.73\%), $9.97 \mathrm{~g}$ of proteins (12.90\%) and $8.01 \mathrm{~g}$ of lipids (10.37\%). After feeding, participants remained at rest for 15 minutes before the beginning of exercise.

Aerobic exercise was performed on a treadmill without inclination for 36 minutes at an intensity of $65 \%$ of the estimated $\mathrm{VO}_{2}$ max. The speed of the exercise was calculated according to the formula proposed by the American College of Sports Medicine ${ }^{20}$ :

$$
\mathrm{VO}_{2}=3,5+(0,2 * \text { speed })+(0,9 * \text { speed } * \% \text { grade })
$$

In both situations, participants were submitted to two BP measurements with an automatic device (Microlife BP A100, Microlife Corporation, Widnau, Switzerland): after 15 minutes of rest and immediately after exercise. Heart rate was measured and recorded (FT1, Polar, Finland) on two occasions in both situations: after 15 minutes of rest and at the last minute of the exercise. The higher HR found in the last minute of the protocol was considered the post exercise HR. RPP was calculated as HR multiplied by systolic BP.

\section{Statistical analyses}

All analysis was performed using the Statistical Package for Social Sciences (IBM SPSS, IBM Corporation, Armonk, NY, USA, 21.0) for Mac OS X. Data normality distribution was verified using the Shapiro-Wilk test. Analysis of variance (repeated measures Factorial ANOVA) 2x2 (status $x$ moment) was employed to evaluate systolic, diastolic and mean $\mathrm{BP}$, as well as HR and RPP before and after exercise in both experimental conditions. Where significant differences and interaction between the effects were found, the Bonferroni multiple comparison test was applied. The effect size (ES) of the differences at pre-and post-moments was calculated according to the following equation ${ }^{21}$.

\section{Pre-Post ES $=($ Posttest mean - Pretest mean $) /$ Pretest SD}

Paired t-test was adopted to compare the percentage of maximum HR achieved at the end of testing in both conditions. The level of significance was set at $p<0.05$. Data are expressed as mean and standard deviation (SD).

\section{RESULTS}

Sample characteristics are shown in Table 1. All ten male subjects completed the experiment. None of them requested for interrupting the exercise in any of the two protocols. Running velocity in fasting and postprandial conditions was $8.54 \pm 1.12 \mathrm{~km} / \mathrm{h}$. The percentage of maximum $\mathrm{HR}$ reached in the last minute of the two protocols showed no significant difference $(72.59 \pm 5.23 \%$ vs $71.62 \pm 5.50 \% ; p=0.593)$. In addition, analysis of variance showed that dependent variables (BP, HR and RPP) were not significantly different between fasting and postprandial conditions at pre-and post exercise moments.

Table 2 presents the outcomes of BP (systolic, diastolic and mean), HR and RPP before and after exercise in the fasting condition. HR and RPP were significantly higher after the exercise $(p<0.01)$, while BP did not change significantly ( $p>0.05$ ) (Table 2$)$.

Results from the exercise in the postprandial condition are presented in Table 3. Similar to the fasting condition, HR and RPP increased significantly after the protocol $(p<0.01)$. However, contrary to the fasting condition, systolic, diastolic and mean BP presented a significant increase after the postprandial protocol $(p \leq 0.01)$ (Table 3 ).

In general, the present results show that ES values ranged from small $(0.35-0.80)$ to large $(>1.5)^{21}$. Of note, higher ES values were observed for all variables in the postprandial condition (Tables 2 and 3 ).
Table 1. Sample characteristics.

\begin{tabular}{|c|c|}
\hline Variable & Mean \pm Standard deviation \\
\hline Age (years) & $25.5 \pm 2.22$ \\
\hline Weight (kg) & $88.43 \pm 10.71$ \\
\hline Height (m) & $1.80 \pm 0.06$ \\
\hline $\operatorname{BMI}\left(\mathrm{kg} / \mathrm{m}^{2}\right)$ & $27.11 \pm 4.28$ \\
\hline Body fat (\%) & $22.39 \pm 8.26$ \\
\hline Absolute $\mathrm{VO}_{2} \max (\mathrm{L} / \mathrm{min})$ & $4.23 \pm 0.59$ \\
\hline Relative $\mathrm{VO}_{2} \max (\mathrm{ml} / \mathrm{kg} / \mathrm{min})$ & $48.75 \pm 6.67$ \\
\hline Maximal HR-estimated (bpm) & $194.5 \pm 2.22$ \\
\hline Resting HR (bpm) & $68.67 \pm 10.95$ \\
\hline Resting SBP (mmHg) & $125.9 \pm 10.57$ \\
\hline Resting DBP (mmHg) & $71.1 \pm 8.62$ \\
\hline
\end{tabular}

BMI: Body mass index; $\mathrm{VO}_{2}$ max: Maximal oxygen consumption; HR: Heart rate; SBP: Systolic blood pressure; DBP: Diastolic blood pressure.

Table 2. Dependent variables in the fasting condition (Mean \pm SD).

\begin{tabular}{c|c|c|c|c}
\hline Variable & Pre & Post & p & ES \\
\hline Systolic BP $(\mathrm{mmHg})$ & $126.3 \pm 7.0$ & $130.1 \pm 12.2$ & 0.93 & 0.54 \\
\hline Diastolic BP $(\mathrm{mmHg})$ & $71.6 \pm 8.6$ & $80.5 \pm 7.0$ & 0.20 & 1.03 \\
\hline Mean BP $(\mathrm{mmHg})$ & $89.8 \pm 7.5$ & $97.0 \pm 7.8$ & 0.25 & 0.96 \\
\hline HR $(\mathrm{bpm})$ & $64.2 \pm 15.9$ & $141.2 \pm 10.3$ & 0.0001 & 4.84 \\
\hline RPP $(\mathrm{mmHg}$ (bpm) & $8052.1 \pm 1790.7$ & $18382.6 \pm 2341.7$ & 0.0001 & 5.77 \\
\hline
\end{tabular}

BP: Blood pressure; HR: Heart rate; RPP: Rate pressure product; ES: Effect size.

Table 3. Dependent variables in the postprandial condition (Mean \pm SD).

\begin{tabular}{c|c|c|c|c}
\hline Variable & Pre & Post & p & ES \\
\hline Systolic BP $(\mathrm{mmHg})$ & $121.7 \pm 7.8$ & $139.8 \pm 12.9$ & 0.01 & 2.32 \\
\hline Diastolic BP $(\mathrm{mmHg})$ & $66.4 \pm 9.8$ & $80.2 \pm 8.7$ & 0.003 & 1.41 \\
\hline Mean BP (mmHg) & $84.8 \pm 2.8$ & $100.1 \pm 2.2$ & 0.001 & 5.46 \\
\hline HR (bpm) & $63.6 \pm 8.8$ & $139.2 \pm 10.8$ & 0.0001 & 8.59 \\
\hline RPP (mmHg*bpm) & $7772.6 \pm 1413.8$ & $19564.6 \pm 3128.9$ & 0.0001 & 8.34 \\
\hline BP: Blood pressure; HR: Heart rate; RPP: Rate pressure product; ES: Effect size. & &
\end{tabular}

\section{DISCUSSION}

This study investigated BP, HR and RPP responses to a 36 minutes' duration aerobic exercise at $65 \%$ of the $\mathrm{VO}_{2}$ max performed in the fasting state and after feeding. The results showed a significant increase in systolic, diastolic and mean BP only after the postprandial exercise condition, while HR and RPP increased significantly in both protocols. It is known that systolic BP increment during exercise is related to the maximization of the sympathetic activity in order to elevate HR and cardiac output and to promote a greater blood flow to the working muscles ${ }^{22}$. Furthermore, systolic BP augmentation induced by exercise is related to the endothelial vasodilator function ${ }^{23}$. 
Interestingly, the findings presented in this study appear to be the opposite of those reported in previous literature. Although exercise in the fasting state stimulate the secretion of catecholamines ${ }^{5}$, the present report shows that there was an increase in systolic BP only in the postprandial protocol. In this sense, food intake seems to have influenced systolic BP prior to exercise. According to Vanis et al. ${ }^{13}$, glucose intake promotes insulin secretion, resulting in a greater release of norepinephrine and epinephrine. When this phenomenon does not occur (e.g. because of a failure in the sympathetic nervous system), postprandial hypotension may happen ${ }^{13}$. Worthy of note, none of the subjects presented postprandial hypotension in the present investigation.

The non-occurrence of a significant rise in systolic BP after exercise in the fasting state would suggest a dysfunction in sympathetic activity of the participants with a consequent failure to catecholamine secretion ${ }^{12}$. Nevertheless, HR increased significantly in both situations. Moreover, participants of this study were physically active and used to the exercise intensity adopted in the experimental protocol. In this sense, cardiovascular alterations during exercise were not expected to be so high.

Although the results of this study do not indicate a significant difference between pretest measurements in both protocols, systolic BP at the postprandial session presented a lower resting value compared to the fasting session ( $121.70 \pm 7.80$ vs $126.30 \pm 6.98 \mathrm{mmHg} ; \mathrm{p}>0.05)$. Therefore, the non-occurrence of a significant rise in systolic BP after exercise in the fasting state may be related to the higher resting values observed at this session.

On the other hand, glucose intake and the increase in plasma insulin concentration promote a higher activity of the sympathetic nervous system, stimulating alterations in cardiac autonomic function, $\mathrm{HR}$ variability and $\mathrm{BP}^{14}$. Thus, the significant increase in systolic $\mathrm{BP}$ induced by exercise in the postprandial condition can also be explained by the high glycemic load contained in the provided meal, since glucose intake induces a marked increase of insulin production and release ${ }^{24}$. Also, insulin has vasodilating properties related to the increase in nitric oxide secretion by vascular endothelial cells, resulting in a reduction of peripheral vascular resistance and $B P$. Hereupon, the behavior of BP in response to exercise in fasting and postprandial conditions relates to the variation in insulin concentration, caused by the ingestion or restriction of food. This behavior appears to depend on a balance between the vasodilator effect of insulin (e.g. associated with the release of nitric oxide) and the consequent reduction in peripheral vascular resistance, and its vasoconstrictor activity characterized by the stimulation of the sympathetic nervous system and the secretion of norepinephrine ${ }^{15}$.

It is shown in the literature that diastolic BP response to exercise is mediated by the vasodilation capacity of peripheral vessels and the consequent reduction in peripheral vascular resistance ${ }^{25}$. Ordinarily, diastolic BP remain constant or show small increases during submaximal or maximal aerobic exercise ${ }^{22,26}$. In this study, diastolic BP increased significantly only after exercise in the postprandial condition. This result could be explained by a hyperactivity of the sympathetic nervous system and increased vascular response to adrenergic stimulation ${ }^{25,27}$. However, this pattern should be also noted after the exercise in the fasting state, since that condition promotes a greater secretion of catecholamines ${ }^{5}$. So, it is more likely that this diastolic BP result be related to the same reasons mentioned for systolic BP.

Both protocols promoted a substantial increase in HR. This increase occurs mainly due to the increasing blood flow and cardiac output requirement, to redirect the oxygenated blood to active muscles ${ }^{22}$. Even though glucose intake and increased insulin concentrations induce changes in $\mathrm{HR}$ response to exercise ${ }^{14}$, the present investigation showed that postprandial exercise promotes a similar HR response compared to fasted exercise.

The RPP, also referred to as Double Product (systolic BP multiplied by HR), is a surrogate measure of myocardial oxygen demand and cardiac workload ${ }^{28}$. According to Nagpal et al. ${ }^{29}$, RPP correlates well with myocardial oxygen consumption $\left(\mathrm{MVO}_{2}\right)$ in patients with ischemic heart disease. Thus, the assessment of RPP can potentially indicate a dysfunction of the autonomic nervous system (e.g. sympathetic stimulation $)^{30}$. Despite the expected sympathetic activation difference between exercise in fasting and postprandial state, the present study shows that RPP increased significantly and similarly after both protocols. Once RPP is the product of systolic BP and HR, this result may be related to an increase in sympathetic stimulation to the heart combined to a decrease in sympathetic stimulation to the blood vessels ${ }^{31}$.

The present investigation has some limitations. Firstly, the sample was small and consisted only of trained young men with no musculoskeletal, metabolic or cardiovascular diseases. Therefore, these results should not be extrapolated to women, patients suffering from diseases, obese or sedentary. Secondly, the exercise protocol adopted in this study consisted of 36 minutes of aerobic exercise on a treadmill at $65 \%$ of the $\mathrm{VO}_{2}$ max. So, these results should not be generalized to different intensities or exercise duration, since BP and $H R$ respond differently to distinct efforts. Finally, plasma catecholamines were not quantified and could elucidate some of the issues raised in this report.

Nonetheless, to the best of our knowledge, this is the first study to compare cardiovascular responses to exercise in fasting and postprandial states in a sample of physically active men. Hence, the present report provides novel and important information on the topic. Future studies should be conducted trying to address the limitations of the present investigation, with special attention to plasma catecholamines concentration.

\section{CONCLUSION}

In summary, moderate aerobic exercise performed after the postprandial session promoted a significant increase in systolic, diastolic and mean BP. This result was not observed after the fasting protocol. Despite of the expected difference of the endocrine response between the two protocols, both conditions induced significant increases of HR and RPP. Based on this results, it may be suggested that the increased secretion of catecholamines in the fasted exercise is not enough to significantly alter BP. Moreover, it is possible to infer that the meal provided before the postprandial exercise caused a greater responsiveness of BP to exercise.

All authors declare no potential conflict of interest related to this article.

AUTHORS' CONTRIBUTIONS: Each author made significant individual contributions to this manuscript. MRM (0000-0003-0881-305X)* designed the study, supervised data collection and interpretation, wrote the draft, revised the manuscript. SNC (0000-0003-4936-1109)* performed data collection, statistical analysis and helped to wrote the manuscript. MTD (0000-0001-6245-3337)* helped to interpret data and to wrote the manuscript, revised the manuscript. RJO (0000-0002-1232-0488)* and RAED (00000002-2935-8642)* designed the study, supervised data collection, and revised the manuscript. FDL (0000-0001-5748-7540* designed the study, performed data collection, statistical analysis and data interpretation, helped to wrote the manuscript. *ORCID (Open Researcher and Contributor ID). 


\section{REFERENCES}

1. De Bock K, Richter EA, Russell AP, Eijnde BO, Derave W, Ramaekers M, et al. Exercise in the fasted state facilitates fibre type-specific intramyocellular lipid breakdown and stimulates glycogen resynthesis in humans. J Physiol. 2005;564(Pt 2):649-60.

2. Shimada $K$, Yamamoto Y, Iwayama $K$, Nakamura $K$, Yamaguchi S, Hibi M, et al. Effects of post-absorptive and postprandial exercise on $24 \mathrm{~h}$ fat oxidation. Metabolism. 2013;62(6):793-800.

3. Johnson NA, van Overbeek D, Chapman PG, Thompson MW, Sachinwalla T, George J. Effect of prolonged exercise and pre-exercise dietary manipulation on hepatic triglycerides in trained men. Eur J Appl Physiol. 2012;112(5):1817-25.

4. de Lima FD, Correia AL, Teixeira Dda S, da Silva Neto DV, Fernandes ÍS, Viana MB, et al. Acute metabolic response to fasted and postprandial exercise. Int J Gen Med. 2015;8:255-60.

5. Bahr R, Hansson P, Sejersted OM. Triglyceride/fatty acid cycling is increased after exercise. Metabolism. 1990;39(9):993-9.

6. Deighton K, Zahra JC, Stensel DJ. Appetite, energy intake and resting metabolic responses to $60 \mathrm{~min}$ treadmill running performed in a fasted versus a postprandial state. Appetite. 2012;58(3):946-54

7. Paoli A, Marcolin G, Zonin F, Neri M, Sivieri A, Pacelli QF. Exercising fasting or fed to enhance fat loss? Influence of food intake on respiratory ratio and excess postexercise oxygen consumption after a bout of endurance training. Int J Sport Nutr Exerc Metab. 2011;21(1):48-54.

8. Faria VC, Marins JCB, Oliveira GA, Sales SS, Reis FF, Pereira JC, et al. Metabolic response to different glycemic indexes of pre-exercise meal. Rev Bras Med Esporte. 2015;21(4):287-91.

9. Maughan RJ, Fallah J, Coyle EF. The effects of fasting on metabolism and performance. Br J Sports Med 2010;44(7):490-4

10. Coulson JM. The relationship between blood pressure variability and catecholamine metabolites: a pilot study. J Hum Hypertens. 2015;29(1):50-2.

11. Lipsitz LA, Pluchino FC, Wei JY, Minaker KL, Rowe JW. Cardiovascular and norepinephrine responses after meal consumption in elderly (older than 75 years) persons with postprandial hypotension and syncope. Am J Cardiol. 1986;58(9):810-5.

12. Wheatley CM, Snyder EM, Johnson BD, Olson TP. Sex differences in cardiovascular function during submaximal exercise in humans. Springerplus. 2014;3:445.

13. Vanis L, Gentilcore D, Rayner CK, Wishart JM, Horowitz M, Feinle-Bisset C, et al. Effects of small intestinal glucose load on blood pressure, splanchnic blood flow, glycemia, and GLP-1 release in healthy older subjects. Am J Physiol Regul Integr Comp Physiol. 2011;300(6):R1524-31.

14. Quilliot D, Zannad F, Ziegler O. Impaired response of cardiac autonomic nervous system to glucose load in severe obesity. Metabolism. 2005;54(7):966-74.

15. Bardwell WA, Ziegler MG, Dimsdale JE. Influence of cholesterol and fasting insulin levels on blood pressure reactivity. Psychosom Med. 2000;62(4):569-75.

16. Madden KM, Tedder G, Lockhart C, Meneilly GS. Oral glucose tolerance test reduces arterial baroreflex sensitivity in older adults. Can J Physiol Pharmacol. 2008;86(3):71-7.

17. Jones KL, O'Donovan D, Russo A, Meyer JH, Stevens JE, Lei Y, et al. Effects of drink volume and glucose load on gastric emptying and postprandial blood pressure in healthy older subjects. Am J Physiol Gastrointest Liver Physiol. 2005;289(2):G240-8.

18. Williams TD, Chambers JB, May OL, Henderson RP, Rashotte ME, Overton JM. Concurrent reductions in blood pressure and metabolic rate during fasting in the unrestrained SHR. Am J Physiol Regul Integr Comp Physiol. 2000;278(1):R255-62.

19. Jackson AS, Pollock ML. Generalized equations for predicting body density of men. Br J Nutr. 1978;40(3):497-504

20. American College of Sports Medicine. ACSM's guidelines for exercise testing and prescription. 9th ed. Philadelphia:Wolters Kluwer/Lippincott Williams \& Wilkins Health; 2014.

21. Rhea MR. Determining the magnitude of treatment effects in strength training research through the use of the effect size. J Strength Cond Res. 2004;18(4):918-20.

22. LeW, MitikuT, Sungar G, Myers J, FroelicherV. The blood pressure response to dynamic exercise testing: a systematic review. Prog Cardiovasc Dis. 2008;51(2):135-60.

23. Stewart KJ, Sung J, Silber HA, Fleg JL, Kelemen MD, Turner KL, et al. Exaggerated exercise blood pressure is related to impaired endothelial vasodilator function. Am J Hypertens. 2004;17(4):314-20.

24. Roberts S, Desbrow B, Grant G, Anoopkumar-Dukie S, Leveritt M. Glycemic response to carbohydrate and the effects of exercise and protein. Nutrition. 2013;29(6):881-5.

25. Miyai N, Arita M, Miyashita K, Morioka I, ShiraishiT, Nishio I. Blood pressure response to heart rate during exercise test and risk of future hypertension. Hypertension. 2002;39(3):761-6.

26. Franz IW. Ergometry in the assessment of arterial hypertension. Cardiology. 1985;72(3):147-59.

27. Kavey RE, Kveselis DA, Gaum WE. Exaggerated blood pressure response to exercise in children with increased low-density lipoprotein cholesterol. Am Heart J. 1997;133(2):162-8.

28. Fornitano LD, Godoy MF. Increased rate-pressure product as predictor for the absence of significant obstruc tive coronary artery disease in patients with positive exercise test. Arq Bras Cardiol. 2006;86(2):138-44

29. Nagpal S, Walia L, Lata H, Sood N, Ahuja GK. Effect of exercise on rate pressure product in premenopausal and postmenopausal women with coronary artery disease. Indian J Physiol Pharmacol. 2007;51(3):279-83.

30. Atkinson G, Leary AC, George KP, Murphy MB, Jones H. 24-hour variation in the reactivity of ratepressure-product to everyday physical activity in patients attending a hypertension clinic. Chronobiol Int. 2009;26(5):958-73.

31. Forjaz CL, Matsudaira Y, Rodrigues FB, Nunes N, Negrão CE. Post-exercise changes in blood pressure, heart rate and rate pressure product at different exercise intensities in normotensive humans. Braz Med Biol Res. 1998;31(10):1247-55. 